\title{
Paraspinal extramedullary haematopoiesis: a rare radiological diagnosis
}

\author{
Sean Carter, ${ }_{1}^{1}$ Manfred Spanger, ${ }^{1}$ Minu Koshy, ${ }^{2}$ Laurence Weinberg (1) 3,4
}

${ }^{1}$ Department of Radiology, Box Hill Hospital, Box Hill, Victoria, Australia

${ }^{2}$ Department of Anatomical Pathology, Austin Health, Heidelberg, Victoria, Australia ${ }^{3}$ Department of Anaesthesia, Austin Health, Heidelberg, Victoria, Australia

${ }^{4}$ Department of Critical Care, The University of Melbourne, Melbourne, Victoria, Australia

\section{Correspondence to} Professor Laurence Weinberg; laurence.weinberg@austin. org.au

Accepted 6 February 2022
Check for updates

(C) BMJ Publishing Group Limited 2022. No commercial re-use. See rights and permissions. Published by BMJ.

To cite: Carter $S$, Spanger $M$, Koshy $\mathrm{M}$, et al. BMJ Case Rep 2022;15:e248559. doi:10.1136/bcr-2021248559

\section{DESCRIPTION}

Paraspinal extramedullary haematopoiesis (PEH) is a heterogeneous and rare condition where insufficient bone marrow haematopoiesis results in ectopic haematopoietic tissue forming in the paraspinal or posterior paracostal spaces. ${ }^{12}$ Causes include myelofibrosis and haemoglobinopathies, such as sickle-cell disease or thalassaemia. ${ }^{2-4}$ While histological sampling is the gold standard for diagnosis, PEH may be diagnosed radiologically. As such, it is important to understand the radiological features of PEH.

A fit and well middle-aged man presented with nausea, vomiting and fever. There was no history of travel, malignancy, vascular or infective disorders. Initial blood tests showed a normochromic, normocytic anaemia with raised inflammatory markers (C reactive protein, serum ferritin, platelets and white cell counts). Iron studies showed low serum iron, low serum transferrin and transferrin saturation. Liver function tests were mildly elevated. These results were suggestive of an inflammatory process in conjunction with a chronic anaemia. A chest X-ray revealed a left-sided paravertebral density that appeared separate to the descending aortic silhouette. A subsequent contrast CT scan of the abdomen and pelvis revealed a large retroperitoneal mass at the thoracolumbar junction, which encased the aorta and extended into the paraspinal space (figure 1). There was extensive pararenal soft tissue with heterogeneous enhancement. Histopathology from a paraspinal and periaortic mass biopsy showed haematopoietic tissue with a small amount of fibrous stroma. The tissue contained a variety of cells including megakaryocytes, without significant fibrosis or malignant infiltrate (figure 2).

Radiological features of extramedullary haematopoiesis vary depending on location, lesion activity

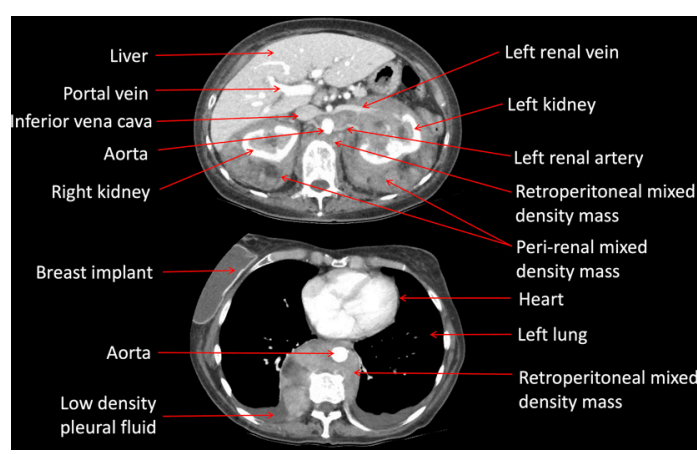

Figure 1 Contrast CT of abdomen (top) and chest (bottom) with paraspinal, perirenal and retroperitoneal masses.

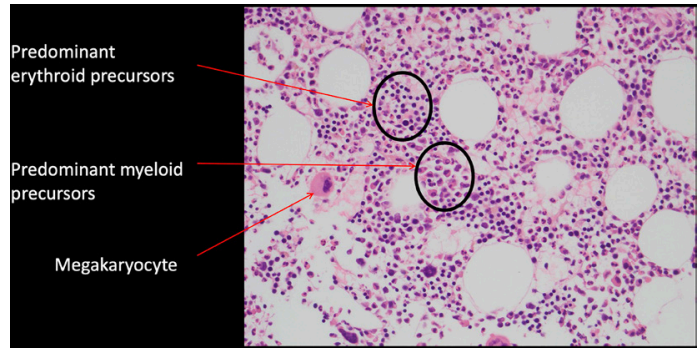

Figure 2 Extramedullary haematopoeisis. High power section demonstrating a mixture of erythroid and myeloid precursors with scattered megakaryocytes.

and lesion age. Masses may be infiltrative, well or poorly defined, and are commonly multifocal. ${ }^{2}$ As seen in this case, PEH presented with large dense paraspinal and posterior paracostal masses. ${ }^{4}$ While not a prominent feature of this case, lesions in the spine can cause compression and subsequent pain, paraesthesia, weakness, paralysis, bladder and bowel problems. ${ }^{5}$ Lesions can be unilateral or bilateral and multifocality is common. ${ }^{2}$ Acute lesions may have similar features to neoplasms whereas older lesions are easier to diagnose due to fat or haemosiderin deposits. New sites of extramedullary haematopoiesis undergo active haematopoiesis. As such, they are hypoattenuating on CT, with mild to moderate homogeneous enhancement when viewed postcontrast. $^{2}$ Conversely, older lesions display attenuation similar to skeletal muscle, often with fatty infiltration, and are unlikely to show calcification. Postcontrast there is minimal to no enhancement. However, it is important to note that features of both new and older lesions may be present.

In this case, the patient's chronic anaemia of unclear aetiology, combined with chest X-ray and CT findings increased clinical suspicion of extramedullary haematopoiesis. While history taking is crucial to confirm any blood disorders or exclude other causes such as malignancy or vascular or infective disorders, ${ }^{25}$ the radiological characteristics

\section{Learning points}

Extramedullary haematopoiesis can present with paraspinal or posterior paracostal masses.

- Radiologically, acute lesions may mimic neoplasms, whereas older lesions may be easier to identify due to fat or haemosiderin deposits.

- Histological sampling is the gold standard for diagnosis for paraspinal extramedullary haematopoiesis. 
of the masses can provide additional information to guide diagnosis. In the present case, the patient was treated with a blood transfusion, hydroxyurea and radiotherapy and made an uneventful recovery.

Contributors SC and MS were the lead authors for this case report. MS and SC led the initial patient care and management and reported all the radiological images. MK was the anatomical pathologist involved in the reporting of the pathology and images and LW was the coordinating author, who prepared all the images, helped with the literature review and played a significant part in the write up of the manuscript.

Funding The authors have not declared a specific grant for this research from any funding agency in the public, commercial or not-for-profit sectors.

Competing interests None declared.

Patient consent for publication Consent obtained directly from patient(s).

Provenance and peer review Not commissioned; externally peer reviewed.
Case reports provide a valuable learning resource for the scientific community and can indicate areas of interest for future research. They should not be used in isolation to guide treatment choices or public health policy.

\section{ORCID iD}

Laurence Weinberg http://orcid.org/0000-0001-7403-7680

\section{REFERENCES}

1 Holden C, Hennessy O, Lee W-K. Diffuse mesenteric extramedullary hematopoiesis with ascites: sonography, CT, and MRI findings. AJR Am J Roentgenol 2006;186:507-9.

2 Malla S, Razik A, Das CJ, et al. Marrow outside marrow: imaging of extramedullary haematopoiesis. Clin Radiol 2020;75:565-78.

$3 \mathrm{Kim} \mathrm{CH}$. Homeostatic and pathogenic extramedullary hematopoiesis. J Blood Med 2010;1:13-19.

4 Georgiades CS, Neyman EG, Francis IR, et al. Typical and atypical presentations of extramedullary hemopoiesis. AJR Am J Roentgenol 2002;179:1239-43.

5 Haidar R, Mhaidli H, Taher AT. Paraspinal extramedullary hematopoiesis in patients with thalassemia intermedia. Eur Spine J 2010;19:871-8.

Copyright 2022 BMJ Publishing Group. All rights reserved. For permission to reuse any of this content visit https://www.bmj.com/company/products-services/rights-and-licensing/permissions/

BMJ Case Report Fellows may re-use this article for personal use and teaching without any further permission.

Become a Fellow of BMJ Case Reports today and you can:

- Submit as many cases as you like

Enjoy fast sympathetic peer review and rapid publication of accepted articles

- Access all the published articles

- Re-use any of the published material for personal use and teaching without further permission

\section{Customer Service}

If you have any further queries about your subscription, please contact our customer services team on +44 (0) 2071111105 or via email at support@bmj.com.

Visit casereports.bmj.com for more articles like this and to become a Fellow 